\title{
Social and Environmental Sustainability: An Empirical Analysis of Supply Chain Profitability and the Recession
}

\author{
Trisha Anderson \\ School of Business Administration, \\ Texas Wesleyan University, Fort Worth, TX, 76105 \\ Email: trdanderson@txwes.edu (Corresponding Author) \\ Zugang Liu \\ Department of Business and Economics, \\ Pennsylvania State University, Hazleton, PA, 08071 \\ Email: zx123@psu.edu
}

\author{
Jose Cruz \\ Department of Operations and Information Management, School of Business \\ University of Connecticut, Storrs, CT, 06269 \\ Email: jose.m.cruz@uconn.edu \\ Jia Wang \\ Rohrer College of Business, \\ Rowan University, 201 Mullica Hill Road, Glassboro, New Jersey 08028 \\ Email:wangji@rowan.edu
}

\begin{abstract}
With the looming possibility of another recession, firms are wondering if their supply chain will be ready. This research helps firms understand the impacts of environmental and socially responsible activities on the financial performance of firms before and after the $\mathbf{2 0 0 8}$ recession at different stages of the supply chain that includes four industries: Retail, Wholesale, Manufacturing, and Transportation. We found that the financial impacts of the Corporate Social Responsibility (CSR) activities on supply chain firms have changed since the financial crisis in $\mathbf{2 0 0 8}$ and that only in the retail industry both positive environmental and socially responsible activities have consistent positive impacts on the companies' profitability. The impacts of positive activities are mixed for the other supply chain industries. The negative environmental activities consistently have negative financial impacts on companies across all supply chain industries. In the transportation industry, negative social activities are consistently associated with positive financial impacts.
\end{abstract}

Keywords: supply chain management, corporate social responsibility, sustainability, corporate social and financial performance, dynamic panel regression model

\section{INTRODUCTION}

Today, firms are integrating Corporate Social Responsibility (CSR) into various aspects of their businesses (Harjoto and Jo, 2011), for example, Fortune 1000 companies in the US are regularly issuing CSR reports (Galema et al., 2008). Carroll (1979) defined four categories of CSR including economic, legal, ethical, and discretionary/philanthropic responsibilities. The study also described the economic responsibility as "to produce goods and services that society desires and to sell them at a profit," which is consistent with the financial objective of a corporation. The legal responsibilities are the obligations imposed by laws and regulations which companies must assume. According to Carroll (1979), "the economic and legal responsibilities are required, the ethical responsibility is expected, and the discretionary/philanthropic responsibility is desired." Carroll and Shabana (2010) argued that the essence of CSR is ethical and philanthropic responsibilities. The business incentives of corporations to engage in CSR activities may include reducing risk and cost, building a reputation, developing a competitive advantage, supporting broad corporate strategy (Zadek, 2000), etc. For instance, the CSR engagement of a supplier will increase the loyalty and trust of its customers. In particular, philanthropic CSR activities will increase customer-company identification (Homburg et al., 2013). For another example, Bauman and Skitka (2012) argued that a company's CSR engagement would strengthen the trust and commitment of employees, increase organizational attractiveness, which would help recruit and maintain employees.

Nevertheless, the debate over CSR has centered on whether investments in CSR activities create value or whether they are adding unnecessary costs to the firm. Supporters of CSR suggest that investments in CSR activities are necessary for firms to undertake. Many studies 
have shown a positive relationship between CSR and corporate performance (Shen and Chang, 2008; Wang et al., 2008; Lee et al., 2018). Moreover, Heal (2005) suggested that externalization of part of the production cost is one of the reasons why some firms select to act irresponsibly. Other views argue that CSR activities represent a costly diversion of limited resources. This view is discussed and studied by many researchers (see, for example, Brammer et al., 2005, Becchetti et al., 2007, Shen and Chang, 2008, Barnett, 2007, Wang et al., 2008, Lee et al., 2018).

Management attention has moved from competition between firms to competition between supply chains (Christopher, 2005). Concepts such as supply chain sustainability (Koplin et al., 2007), triple bottom line (Elkington, 1997), environmental management (Handfield et al., 2005), and Corporate Social Responsibility (CSR) in supply chains (Pedersen and Andersen, 2006; Maloni and Brown, 2006), to name a few, are receiving growing attention in academia as well as mass media. Companies promote that they are engaging in CSR activity throughout the supply chain as they distribute environmental annual reports that tote sustainability strategies and voluntary initiatives (Andersen and Skjoett-Larsen, 2009), such as Walmart's claim in its 2018 Global Responsibility Report to a commitment to meeting consumer expectations and eliminating abuses in the supply chain (Walmart, 2018). However, despite CSR claims there is a claim that a gap exists between supply chain sustainability efforts in theory and the actual implementation of sustainability in supply chains in practice (Bowen et al., 2006). We empirically and holistically study the CSR activities in the supply chain and this enables us to find evidence of whether only those firms in the supply chain that are visible to customers (i.e. the Retailer or Manufacturer) engage in CSR activities, or whether CSR is embedded in the supply chain culture of these supply chains of these multinational corporations.

Additionally, there is evidence to show that as a result of economic decline, CSR and the overall attitude of companies towards socially responsible activities are affected. To estimate the future from the past, especially with claims of a possible recession hitting the U.S soon by Nobelwinning economist Paul Krugman (Decambre, 2019), we examine how the past recession affected CSR activities in the supply chain. According to a survey conducted by the Factum Invenio in 2009 for Czech Donors Forum, two-thirds of Czech citizens believed that the economic crisis affects, among other areas, the socially responsible behavior of corporations (Placier, 2011). Green and Peloza (2011) found that during the 2008-2009 recession consumers had a heightened focus on value and scrutiny on purchases. Furthermore, advertising research suggests that when firms continue to invest in advertising throughout an economic downturn, they enjoy a higher level of consumer awareness after the recession (Srinivasan et al., 2005). Sakunasingha et al. (2018) showed that overall the firms did not reduce the CSR activities during the 2008 recession, and some CSR activities are more strategically important than others. Our research sheds light on the relationship between the CSR behavior of firms and the impacts on profit before and after a recession.

This research is the first to empirically study CSR activity in the holistic perspective of the supply chain and the impact of the recession. The rest of the paper is organized as follows: Section 2, we present the hypotheses that this research will study and the conceptual model based on those hypotheses; in section 3 a literature review on the state of the art will be discussed; in Section 4, we present the data, methodology and variables construction; in Section 5, we statistically test the hypotheses and present data analysis and results; Section 6, we discuss the results and provide management insights; finally, we conclude with Section 7 and list the limitations of the research.

\section{LITERATURE REVIEW}

The positive connection between CSR and financial performance has been identified in many studies (Waddock and Graves, 1997; Cochran and Wood, 1984). However, most of the studies have shown mixed results. The supporters of firms investing in CSR activities argue that CSR can lead to a decrease in transaction cost, risk, and improve firms' brand and access to capital (Saiia et al., 2003; Fombrun et al., 2000). On the other hand, Barnett (2007) and Becchetti et al. (2007) considered that investment in CSR could negatively affect stakeholders' value. The above formation studies did not explicitly consider the connection between CSR performance and financial returns in the context of the supply chain, within manufacturers, transportation, wholesalers, and retailer industries.

Academics and practitioners have long studied CSR in the manufacturing sector. The manufacturing processes are responsible for converting raw materials into final products that have significant social and environmental impacts. According to the U.S. Department of Commerce, sustainable and responsible manufacturing is defined as "the creation of manufactured products that use processes that minimize negative environmental impacts, conserve energy and natural resources, are safe for employees, communities, and consumers and are economically sound (Haapal et al., 2013; DOC, 2014)." Haapal et al. (2013) reviewed practices in sustainable manufacturing and pointed out that sustainable manufacturing needs to simultaneously consider the economic, environmental, and social implications of the production and logistics processes. The authors discussed the major manufacturing impact areas including energy consumption, airborne emissions, water consumption and wastewater, and solid waste and resource recovery. Regarding material waste, the hierarchy has been well studied and established (Dovi et al., 2009; Despeisse et al., 2012). The top priority and tactic are prevention followed by waste reduction, resource use reduction, reuse, and, finally, substitution. The energy and carbon emission hierarchies can also be developed in a similar manner (Despeisse et al., 2012).

The CSR decisions and activities of a manufacturer affect not only the social responsibility of its manufacturing process but also that of the rest of the supply chain including the delivery, consumption, recycle, and disposition of the product. For example, Linton et al. (2007) discussed how product design impacted supply chain sustainability, byproducts generated by the manufacturing process, byproducts generated by the product use, product life extension, disposition of the end-of-life product, and the endof-life product recovery. Therefore, a Life Cycle Assessment (LCA) has become the most common tool to evaluate the sustainability impact of manufactured goods (Haapal et al., 
2013). Today's complex supply chain networks may have multiple tiers of manufacturers and suppliers. A manufacturer may be the supplier of another manufacturer. Wilhelm et al. (2016) studied the role of the first-tier supplier in the implementation of sustainability requirements in multi-tier supply chains. They pointed out that the first level suppliers have a double-agency role where they need to implement the sustainability needs of the lead firm in their businesses and ensure that these demands are also implemented in their suppliers.

CSR in the transportation industry has focused on the environment, social and ethical issues. The environmental impacts, for example, include the impact on air quality, noises, accidents, and the $\mathrm{CO} 2$ emission contribution to global warming (Carter and Jennings, 2002). Regarding social activities, the issues are working conditions, long hours, and low wages (Murphy and Daley, 1990; Murphy et al., 1991). However, a detailed empirical analysis of the effects of CSR on the financial performance of the transportation industry has been limited to the inclusion of the industry among the control variables (Waddock and Graves, 1997).

The wholesale industry is a vital member of the supply chain. Wholesalers buy a high volume of many products directly from manufacturers and then sell the products to retailers. However, wholesalers have less contact to end customers as compared to the retailers, which can shelter them from market pressure when concerned with CSR activities or lack of it. Investment in CSR activities may help the industry mitigate the risk of fair labor practice claims, employee and customer incidents, regulatory enforcement activity, and other issues that can result in reputation damage (Fombrun, 2005), and lost business (McWilliams and Siegel, 2001).

The firms in the retailer industry are responsible for a broad range of products from a large number of suppliers from many countries while serving a multitude of consumers. Thus, managing CSR activities for the retail industry is challenging. Today, retailers are held responsible for any CSR issues that happen in their supply chain independently if they are responsible or not (Perry and Towers, 2009; Wagner et al., 2008). Indeed, many studies have shown that CSR can influence retailers' brand image and reputation (Burt et al., 2010). Handelman and Arnold (1999) demonstrated that social concern in marketing efforts is needed to support a firms' performance. Ellen et al. (2006) stressed that CSR should be strategically considered by retailers, while Luo and Bhattacharya (2006) argue that CSR is supported as a firm develops a satisfied customer base. Therefore, the retailers are giving high priority and importance to managing CSR activity in their supply chain (Oppewal et al., 2006; McGoldrick and Freestone, 2008).

We note that empirical research on sustainable and responsible supply chain management is limited. Most of the research has focused mostly on environmental concerns, and social matters within the supply chain have not gotten much attention (Seuring and Mller, 2008). Furthermore, detailed empirical analysis of the effects of CSR on the financial performance of the above-listed industries has been limited to the inclusion of them among the control variables (Waddock and Graves, 1997). In this paper, we are trying to fill the gap in the literature by empirically studying the effects of CSR performances on financial returns of the firms in the supply chain (manufacturers, transportation, wholesalers, and retailers) before and after the US market crash of 2008 .

\section{HYPOTHESIS}

In this paper, we analyze the impacts of CSR on the financial returns of firms in the supply chain represented by manufacturers, transportation, wholesalers, and retail industry. In particular, we empirically study the effects of positive and negative environmental and social activities on these supply chain sectors' financial performances, measured by the return on total asset (ROA) before and after the recession of 2009.

We analyze the effects of positive and negative CSR on supply chain financial performance measured by the return on a total asset (ROA) before and after the United States' economic recession of 2009. We control for industry type, the firm capital intensity, and the size. We address how firm's CSR performance (negative and positive) affect its financial performance (represented by ROA) and the impact of a firm's CSR performance on the profitability change after the recession in 2009 by analyzing the following hypotheses:

Hypothesis 1 (H1): A firm's positive environmental responsible performance will be positively related to its financial performance (represented by ROA)

Hypothesis 2 (H2): A firm's negative environmental responsible performance will be negatively related to its financial performance (represented by ROA).

Hypothesis 3 (H3): A firm's positive social responsible performance will be positively related to its financial performance (represented by ROA).

Hypothesis 4 (H4): A firm's negative social responsible performance will be negatively related to its financial performance (represented by ROA).

Hypothesis 5 (H5): The impact of a firm's positive environmental performance on its profitability changed after the recession in 2009.

Hypothesis 6 (H6): The impact of a firm's negative environmental performance on its profitability changed after the recession in 2009.

Hypothesis 7 (H7): The impact of a firm's positive social performance on its profitability changed after the recession in 2009.

Hypothesis 8 (H8): The impact of a firm's negative social performance on its profitability changed after the recession in 2009.

We note that empirical studies analyzing the relationship between CSR and corporate performance, in general, have shown mixed results (see, Brammer et al., 2005, Shen and Chang, 2008, Barnett, 2007, Wang et al., 2008, Lee et al., 2018). In this paper, however, we analyze the effects of positive and negative CSR activities on supply chain settings and expect that effect may not be uniform 
across all the supply chain sectors. In the next sections, we present the results of the hypotheses here.

\section{DATA, METHODOLOGY, AND VARIABLE CONSTRUCTION}

The data for this study was obtained from two databases: MSCI-ESG and Standard and Poor of Compustat $(S \& P)$. MSCI-ESG formerly KLD (Kinder Lyndenberg Dommini) provides a CSR behavior of firms, as an independent rating system. This data set has been applied in many studies (Berman et al., 1999; Harrison and Freeman, 1999). Compustat database provides firms' accounting and financial data. We collected data for firms from Compustat database and MSCI-ESG index for companies that met the following criteria:

1. The firm is either manufacturing (standard industry classification (SIC) code 2000-3999), transportation
(4000-4999), wholesale trade (5000-5199), or retail trade (5200-5999). ${ }^{1}$

2. The firm ESG data was listed in the MSCI-ESG index spanning from 2000 to 2013

3. The firm's financial data is available in the Compustat database from 2000 to 2014

4. The firm was listed in both the MSCI-ESG and in the Compustat database from 2000 to 2014

Applying the above criteria and combining the datasets to match the companies in the Compustat and MSCI-ESG index resulted in a panel data sample of 5199 distinct firms (see Table 1). There are a duplicate unique number of companies if the businesses in the pre-recession dataset are compared with the post-recession dataset, accounting for the fact that the single number of companies pre and postrecession will add to a greater amount than considering the entire pre- and post-recession datasets together.

Table 1 Supply chain industry statistics for the period 2000-2014

\begin{tabular}{|c|c|c|c|}
\hline SIC Code & Industry Title & No. of observations & Unique No. of firms \\
\hline & & 13978 & 3565 \\
\hline \multirow[t]{3}{*}{ 2000-3999 } & Manufacturing & $6367^{a}$ & $1384^{a}$ \\
\hline & & $7611^{b}$ & $3158^{b}$ \\
\hline & & 3390 & 957 \\
\hline \multirow[t]{3}{*}{$4000-4999$} & Transportation & $1491^{a}$ & $323^{a}$ \\
\hline & & $1899 b$ & $865^{b}$ \\
\hline & & 946 & 238 \\
\hline \multirow[t]{3}{*}{ 5000-5199 } & Wholesale Trade & $418^{a}$ & $95^{a}$ \\
\hline & & $528 b$ & $210^{b}$ \\
\hline & & 2316 & 439 \\
\hline \multirow[t]{3}{*}{$5200-5999$} & Retail Trade & $1149 a$ & $223^{a}$ \\
\hline & & $1167 b$ & $383^{b}$ \\
\hline & & 20630 & 5199 \\
\hline \multirow[t]{2}{*}{$2000-5999$} & Total & $9907 a$ & $2025^{a}$ \\
\hline & & $11849 b$ & $4616^{b}$ \\
\hline
\end{tabular}

$\left(a 2000-2008,{ }^{b 2009-2014)}\right.$

We note that due to CSR's multidimensional constructs it is hard to measure it empirically (Surroca et al., 2010). Stanwick and Stanwick (1998) applied Fortune's Corporate Reputation Index to analyze a company's CSR, Prior et al. (2008) used SiRi ProTM data to measure stakeholder's responsibilities, and McGuire et al. (1988) used a Fortune survey of corporate reputations to capture CSR data. Currently, the most accepted measurement of CSR is the MSCI-ESG index, which is regarded as an international standard (Berman et al., 1999; Harrison and Freeman, 1999). As such, the MSCI-ESG index is used to measure CSR performance in the study. MSCI-ESG uses a combination of surveys to construct the indexes based on environmental, social and governance dimensions.

The MSCI ESG STATS indicators used in this study are categorized as environmental and social. Social is further broken down into the community, human rights, employee relations, and diversity activities, with both positive indicators (strengths) and negative indicators (concerns). For example, environmental strengths include the investment in beneficial products and services, pollution prevention, recycling, alternative fuels, communications, as well as others. Environmental concerns include hazardous waste activities, regulatory problems, the use of ozone-depleting chemicals and/or agricultural chemicals, substantial emissions, addressing climate change, etc. (see Table 2). The positive (negative) environmental score of a company is calculated as the average of all indicators in the category of environmental strengths (concerns). The positive (negative) social score of a company is calculated as the average of all strengths (concerns) indicators in all social categories.

\footnotetext{
${ }^{1}$ Each SIC is a division that includes several groups of firms in the industry. For example, the Manufacturing SIC Code (20-39) contains the group code 2011 (Meat Packing Plant) to 3999 (Manufacturing Industries, Not Elsewhere Classified);
} 
Table 2 CSR dimension and definition

\begin{tabular}{|c|c|c|c|c|}
\hline \multirow{2}{*}{ Category } & \multicolumn{2}{|r|}{ Strengths } & \multicolumn{2}{|r|}{ Concerns } \\
\hline & Field Name & Description & Field Name & Description \\
\hline \multirow[t]{7}{*}{ Environment (ENV) } & ENV-str-A & Beneficial Products \& Services & ENV-con-A & Hazardous Waste \\
\hline & ENV-str-B & Pollution Prevention & ENV-con-B & Regulatory Problems \\
\hline & ENV-str-C & Recycling & ENV-con-C & Ozone Depleting Chemicals \\
\hline & ENV-str-D & Alternative Fuels & ENV-con-D & Substantial Emissions \\
\hline & ENV-str-E & Communications (1996 - 2005) & ENV-con-E & Agricultural Chemicals \\
\hline & ENV-str-X & Other Strength & ENV-con-F & Climate Change \\
\hline & & & ENV-con-X & Other Concern \\
\hline \multirow[t]{7}{*}{ Community (COM) } & COM-str-A & Generous Giving & COM-con-A & Investment Controversies \\
\hline & COM-str-B & Innovative Giving & COM-con-B & Negative Economic Impact \\
\hline & COM-str-C & Support for Housing & COM-con-X & Other Concern \\
\hline & COM-str-D & Support for Education & COM-con-D & Tax Disputes (2005-) \\
\hline & COM-str-F & Non-U.S. Charitable Giving & & \\
\hline & COM-str-X & Other Strength & & \\
\hline & COM-str-G & Volunteer Programs Strength (2005-) & & \\
\hline \multirow[t]{4}{*}{ Human Rights (HUM) } & HUM-str-D & Indigenous Peoples Relations & HUM-con-C & Burma \\
\hline & HUM-str-G & Labor Rights Strength & HUM-con-F & International Labor Concern \\
\hline & HUM-str-X & Other Strength & HUM-con-G & Indigenous Peoples Relations \\
\hline & & & HUM-con-X & Other Concern \\
\hline \multirow[t]{7}{*}{ Employee Relations (EMP) } & EMP-str-A & Union Relations Strength & EMP-con-A & Union Relations Concern \\
\hline & EMP-str-C & Cash Profit Sharing & EMP-con-B & Health and Safety Concern \\
\hline & EMP-str-D & Involvement & EMP-con-C & Workforce Reductions \\
\hline & EMP-str-F & Strong Retirement Benefits & EMP-con-D & Pension/Benefits Concern \\
\hline & EMP-str-G & Health and Safety Strength & EMP-con-X & Other Concern \\
\hline & EMP-str-X & Other Strength & & \\
\hline & ENV-str-G & Management Systems (2006-) & & \\
\hline \multirow[t]{8}{*}{ Diversity (DIV) } & DIV-str-A & CEO & DIV-con-A & Employee Discrimination \\
\hline & DIV-str-B & Promotion & DIV-con-B & Non-Representation \\
\hline & DIV-str-C & Board of Directors & DIV-con-X & Other Concern \\
\hline & DIV-str-D & Family Benefits & & \\
\hline & DIV-str-E & Women/Minority Contracting & & \\
\hline & DIV-str-F & Employment of the Disabled & & \\
\hline & DIV-str-G & Progressive Gay/Lesbian Policies & & \\
\hline & DIV-str-X & Other Strength & & \\
\hline
\end{tabular}

Different proxy for the firm's financial performance has been applied in the literature (see Table 3). For example, Stanwick and Stanwick (1998) used a level of profitability (Cowen et al., 1987), Surroca et al. (2010) used Tobin's q, and some researchers used a mixed indicator (Ghosh and $\mathrm{Wu}, 2007)$. In our research, we use the return on assets (ROA), obtained from Standard \& Poor's Compustat and is defined as the ratio of earnings before interest and taxes (EBIT) to the firms book value of total assets (Choi et al., 2010, Cho. 2015, and Ding et al. 2018).

The majority of the prior academic literature found several factors as determinants of CSR investment such as firm size represented by the natural logarithm of the number of employees, capital intensity represented by the ratio of total assets to total sales, the type of industry, and the period (see Table 3). Flammer (2015), and references therein, study the differences between B2C and B2B industries and reported that firms that operate in different industries (classified as "clean" and "dirty" industries) can have different levels of institutional pressure regarding CSR (see also Banerjee et al. (2003), and Shelton Group's 2013 Eco Pulse study (Shelton, 2014)).

The impact of firm size on CSR engagement has been extensively addressed in the literature. The study of Gallo and Jones-Christensen (2011) found that bigger companies engage in more CSR activities since they have more resources and bigger firms receive more press attention (Servaes and Tamayo, 2013). According to Burke et al. (1986), stakeholders pay more attention as firms grow. Udayasankar (2008) found that medium-size firms are less engaged in CSR related activities compared to large and small firms. While Blombck and Wigren (2008) showed that firms' age, size, and type of industry have no significant impact on CSR their performances. Moore (2001) showed that in the supermarket industry company size and CSR performance are strongly positively correlated.

Fama and French (2000) used capital intensity to explain firm financial performance. The assumption here is that higher capital intensity leads to higher financial performance due to innovation and efficiency (McWilliams and Siegel, 2000). As an example, Mwangi and Oyenje 
(2013) studied the connection between CSR activities and the financial performance of firms in several sectors of the Nairobi Securities Exchange then found that CSR had a direct impact on firm financial performance. The study also considered both efficiency and capital intensity and found that they are negatively related to financial performance. In this paper, we also control for $R \& D$ intensity as in Waddock and Graves (1997) through industry dummies.

Finally, we consider the impact of the recession on corporate CSR activity. The literature to date has mainly summarized the effects of qualitatively using surveys and case studies (Placier, 2011) with a focus on policy and practice implications (Ellis and Bastin, 2011). While some have argued that during the recession companies should dismiss CSR, considering it as an economic burden, (Visser et al., 2008), others believe that firms that continue CSR efforts will benefit from a competitive advantage in an increasingly hostile business environment (Ellis and Bastin, 2011; Placier, 2011). The literature aimed at understanding consumer response is also inconclusive as in, for example, Welch (2009) claims that in a recession consumers will be increasingly unable (or unwilling) to pay more for products that support corporate CSR activity, Quelch and Jocz (2009) state that consumer willingness to pay price premiums for brands that have a track record of doing good is a habit that is now entrenched and can survive a recession.

Table 3 Definition and proxy variable for construct

\begin{tabular}{|c|c|c|c|}
\hline Construct & Variable & Definition & Proponent \\
\hline $\begin{array}{l}\text { Corporate Financial Performance } \\
\text { (CFP) }\end{array}$ & ROA & $\begin{array}{l}\text { Return on assets defined } \\
\text { as EBIT/Total Assets }\end{array}$ & $\begin{array}{l}\text { Ding et al. (2018); Jang and Choi (2010); } \\
\text { Choi et al. (2010); Cho (2015) }\end{array}$ \\
\hline $\begin{array}{c}\text { Corporate Social Responsibility } \\
\text { (CSR) }\end{array}$ & MSCI-ESG scores & MSCI-ESG index & $\begin{array}{l}\text { Harrison and Freeman (1999); Berman et } \\
\text { al. (1999); Callan and Thomas (2009) }\end{array}$ \\
\hline \multirow{3}{*}{ Control Variables } & Industry type & $\begin{array}{c}\text { Standard Industry } \\
\text { Classification code (SIC) }\end{array}$ & Waddock and Graves (1997) \\
\hline & Firm size & $\begin{array}{c}\text { Natural logarithm of total } \\
\text { employees }\end{array}$ & $\begin{array}{c}\text { Acquaah and Chi (2007); Callan and } \\
\text { Thomas (2009); Servaes and Tamayo } \\
\text { (2013) }\end{array}$ \\
\hline & Capital Intensity & $\begin{array}{l}\text { Ratio of total assets to } \\
\text { total sales }\end{array}$ & $\begin{array}{c}\text { Russo and Fouts (1997); Farma and } \\
\text { French (2000); Acquaah and Chi (2007); } \\
\text { Callan and Thomas (2009) }\end{array}$ \\
\hline
\end{tabular}

\section{DATA ANALYSIS AND RESULTS}

We study the financial effect for various corporate socially responsible activities that are both positive and adverse over time. We use sample panel data where multiple firms are classified in one of four SIC codes and observed over the period 2000-2014.

The panel data regression models from period 20012008 and 2009-2014 follow the forms (1) and (2) respectively:

$$
\begin{aligned}
R O A_{i j t}= & \beta_{0 j}+\beta_{1 j} L . S O C_{-} P O S_{i j t}+\beta_{2 j} L . S O C_{-} N E G_{i j t}+\beta_{3 j} L . E N V \_P O S_{i j t} \\
& +\beta_{4 j} L . E N V \_N E G_{i j t}+\beta_{5 j} T_{i j t}^{2002}+\ldots+\beta_{11 j} T_{i j t}^{2008}+\beta_{12 j} S I Z E_{-} L o g E M P_{i j t} \\
& +\beta_{13} C I_{i j t}+\mu_{i j t} \quad \forall i=1, \ldots, I, j=1, \ldots, J, \text { and } t=2, \ldots, T, \\
R O A_{i j t}= & \beta_{0 j}+\beta_{1 j} L . S O C_{-} P O S_{i j t}+\beta_{2 j} L . S O C_{-} N E G_{i j t}+\beta_{3 j} L . E N V \_P O S_{i j t} \\
& +\beta_{4 j} L . E N V_{-} N E G_{i j t}+\beta_{5 j} T_{i j t}^{2010}+\ldots+\beta_{9 j} T_{i j t}^{2014}+\beta_{10 j} S I Z E \_L o g E M P_{i j t} \\
& +\beta_{11} C I_{i j t}+\mu_{i j t} \quad \forall i=1, \ldots, I, j=1, \ldots, J, \text { and } t=2, \ldots, T,
\end{aligned}
$$

where $i, j$, and trepresents the number of firms (5199), SIC codes (2000-3999, 4000-4999, 50005199, 5200-5999), and time periods (2000-2014), respectively. L.SOC POS L.SOC NEG $G_{i j t}$, L.ENV POS the one time period lag of corporate environmental and socially responsible activities, both positive and negative related to the environment (note that social includes community, human rights, employee relations, and diversity). As in Razafindrambinina and Sabran (2014), the model has a one year lag between CSR and ROA ensures that the data are synchronous, that is, the CSR investment in year $t$ affects ROA in year $t+1$.

$T_{i j t}$ is each time period as a binary dummy variable with $t-1$ time periods, and $E_{i t}$ represents firm size by the log of the number of employees, and $C I_{i j t}$, represents capital intensity for each firm, time period, and SIC, respectively. The loglinear form used in the model is like many used in applied work in the social sciences and real estate research. Finally, $R O A_{i j t}$ represents the return on assets for each firm, time period, and SIC. $\beta$, in the model (1) and (2) represent the coefficients for CSR involvement in both positive and negative activities $\left(C S R_{i j t}\right)$, and the binary time, firm size, log of employees, capital intensity regressors, respectively.

We balance the dataset (eliminate those firms that did not report data for all years studied) and use Stata12 for the statistical analysis and model verification. We use the $x t g l s$ Stata module that fits cross-sectional time-series linear models using feasible generalized least squares (GLS) estimation to allow more flexible covariance structure for disturbances and random effects. The $x t g l s$ command allows estimation in the presence of autocorrelation within panels and cross-sectional correlation and/or heteroskedasticity across panels. We specify the force command, in which xtgls will fit the model and assume that the lags are appropriate, as 
well as the corr (psar1) command to specify that, within panels, there is autocorrelation and that the coefficient of the process is specific to each panel. Finally, we use the panels (heteroskedastic) which specify heteroskedastic error structure with no cross-sectional correlation.

\subsection{Robustness Tests}

This section discusses the robustness of our results. One of the major concerns with this type of study is endogeneity. We run panel regressions with firm and year fixed effects and with additional control variables that may affect ROA. We include advertising expenditures (as a ratio of advertising expenditures to total assets) and research and development intensity (as a ratio of R\&D expenses to total assets (Acquaah and Chi, 2007). We removed records with missing data for advertising and R\&D expenditures and re-estimate the model. These control variables, when included, were not significant and did not change the results of our study. Additionally, our results are robust to a variety of alternatives for the transformation of the independent variables such as using the current (time period, t) CSR index as well as using a dummy variable for the number of employees as a measure of the size of the firm, both of which do not qualitatively alter the results.

We checked for multicollinearity. As shown in Table 6 and Table 7 (see Appendix), none of the variables is strongly correlated with each other. We checked for autocorrelation of the first degree with Durbin-Watson d. According to Montgomery et al. (2001), Durbin-Watson d statistics typically show no autocorrelation around 1.5 and 2.5. Our results seem to be robust since we had not no multicollinearity and autocorrelation problems in the model.

Finally, we reran the regression model deleting sales values for the manufacturer (2000-2008) that were less than zero (there were two observations). The change in the results is negligible.

Note that we also considered R\&D intensity (Acquaah and Chi, 2007) and marketing intensity (Callan and Thomas, 2009). These control variables, however, were not significant. When considering these control variables, most of the data were eliminated from the analysis because many of the firms in the Retailer, Transportation, and Wholesaler industries do not undertake R\&D activities. Moreover, when concerning to marketing intensity, we also saw a few companies conducting this activity in Manufacturer and Transportation Industries. Therefore, for consistency across all industries, we only consider firm size, capital intensity, industry type, and year as control variables.

\subsection{Impacts of CSR Activities on Supply Chain Firms Financial Performances}

Hypotheses 1 to 4 results (see Table 5 in the Appendix) show the impacts of environmental and socially responsible activities on the profitability of four different supply chain industries.

Hypothesis 1 (H1): A firm's positive environmental responsible performance will be positively related to its financial performance (represented by ROA)

Manufacturer: During the two study periods, environmental positive activities had a negative impact on manufacturers profitability with $\beta=-0.101$, and $\beta=-0.031$ at $1 \%$ level, respectively. Therefore, hypothesis 1 is not supported for manufacturers. The results are in line with the theories that environmental responsible activities, such as pollution prevention, recycling, and the use of alternative fuels, will higher cost and reduce profit. Another alternative explanation for the negative impact of positive environmental activities on manufacturers profits is that many firms consider CSR activities as an insurance or a real option to alleviate future environmental and social risks (Cassimon et al., 2016; Godfrey et al., 2009). In this case, firms consider investments in CSR as the insurance or option premium and use CSR as a risk management tool that incurs a current financial loss to avoid potential disastrous losses in the future.

Transportation: As concern to $\mathrm{H} 1$, the results between the periods 2000-2008 and 2009-2014 show that positive environmental activities had a negative impact on ROA $(\beta=$ -0.079 and $\beta=-0.030$ respectively at $1 \%$ level ). These contradict hypotheses $\mathrm{H} 1$. We conclude that positive activities are both negatively related to return on asset (ROA) which fails to support the hypothesis. Therefore, improving transportation environmental performance may lead to an increasing in firm costs, and therefore negatively affecting the ROA.

Wholesaler: Between the period 2000 - 2008 environment positive is significant and support the hypotheses ( $\beta=0.359$ at $1 \%$ level of significance). However, 2009 - 2014, the coefficient of environment positive is significantly negative $(\beta=-0.028$ at $5 \%$ level of significance). Therefore, results from $2000-2008$ support H1 while results from 2009 - 2014 contradict H1. Such mixed results indicate that the financial crisis and economic recession had made the cost of environmental positive activities outweigh the benefits for wholesalers.

Retailer: Brown and Dacin (1997) quote a manager of a major US retail company saying: "We do all these good things we build buildings, give money away but we dont know if we get anything out of it". Direct environmental impacts (consumers can recognize retailer behavior) include, but are not limited to, forms of energy consumption (electricity by renewable sources), amount of water consumption (i.e. green building), air pollution (including placement of stores for travel by employees and consumers), solid waste generation (paper receipts, paper bags), and offering of green products (organic, selling locally produced products, etc.).

Supporting our hypothesis, our results show that positive environmental activities had a positive impact on ROA. In particular, $\beta=0.308$ at $1 \%$ level of significance between the period 2000-2008, and $\beta=0.055$ at $1 \%$ level of significance between the period $2009-2014$. Laroche et al. (2001) found that married females with at least one child living at home are more likely to pay more for ecofriendly products. Interestingly, Ailawadi et al. (2014) found conflicting results when they studied the effects of consumers, classified into various groups, perceptions of environmental friendliness and selling locally produced products, on their behavioral loyalty toward retailers. Environmental friendliness resulted in negative consumer behavior loyalty for the group of consumers who place more emphasis on promotional deals and price, and less emphasis 
on unique items and quality, and interestingly, places more emphasis on employee fairness (social concerns).

Hypothesis 2 (H2): A firm's negative environmental responsible performance will be negatively related to its financial performance (represented by ROA).

Manufacturer: As we expected, the negative environmental activities have a significantly negative impact on manufacturers profitability. In particular, the coefficient is equal to -0.247 at $1 \%$ level during the period 2001-2008, and equal to -0.231 at $1 \%$ level during the period 2009-2014. Therefore, hypothesis 2 is supported. Negative environmental activities negatively affect a manufacturer's profit due to risk, liability and reputation damages. Moreover, usually, the negative environmental activities are reported when a manufacturer fails to undertake its required and/or expected responsibility, which is expected to have a substantial impact on its financial performance.

Transportation: As concern to $\mathrm{H} 2$, the results between the periods 2000-2008 and 2009-2014 show that negative environmental activities had a negative impact on ROA $(\beta=$ -0.119 and $\beta=-0.139$ respectively at $1 \%$ level ). These support hypotheses $\mathrm{H} 2$. Hence supporting the argument that negative CSR activities affect the financial performance negatively transportation industry due to increasing in risk, liability, and decline of brand image (Saiia et al., 2003). The results are consistent during the period 2000-2008 and 2009 $-2014$.

Wholesaler: Between the period 2000-2008 environment negative is significant and support the hypothesis $(\beta=-0.451,1 \%$ level of significance). Suggesting that negative activity has a higher impact on ROA, as compared to environment positive. Regarding the change between the periods 2000-2008 to 2009-2014, negative environment activities experience a significant change from a larger negative impact on ROA to a lesser negative impact on ROA $(\beta=-0.451$ and $\beta=-0.099$, respectively at $1 \%$ level of significance). The general conclusion for wholesaler industry when concerning with environmental activities is that negative activities have negative effects on ROA. Therefore, negative CSR activities can affect firms reputation and riskiness level(Feldman et al., 1997).

Retailer: Supporting our hypothesis, our results show that between both periods $2000-2008$ and $2009-2014$, negative environmental activities had a negative impact on ROA $(\beta=-0.568$ and $\beta=-0.081$, respectively). Lewis (2001) states that consumers can reward good companies and punish the bad ones using their purchasing power. A study performed by Laroche et al. (2001) revealed that $80 \%$ of consumers who are more likely to spend more for green products say they refuse to buy products from companies accused of being polluters."

Hypothesis 3 (H3): A firm's positive social responsible performance will be positively related to its financial performance (represented by ROA).

Manufacturer: The impact of positive social activities on the manufacturer's profitability is mixed. Between the period of 2000-2008, the coefficient of manufacturer's positive social activities is equal to 0.268 at $1 \%$ level of significance supporting $\mathrm{H} 3$ while between the period $2000-2008, \beta$ is equal to -0.060 at $1 \%$ level of significance contradicting H3. The flip of the sign of $\beta$ is likely because the economic recession in 2008 - 2009 changed the behaviors of consumers and supply chain partners which caused the cost of social positive activities overweight the benefit after 2009 .

Transportation: Between the periods $2000-2008$, social positive had a negative impact on $\operatorname{ROA}(\beta=-0.038)$ at $5 \%$ level of significance. In the period $2009-2014$, the results are similar to the $2000-2008$. Social positive had negative effects on ROA $(\beta=-0.067)$. These contradict hypothesis $\mathrm{H} 3$. For the transportation industry, the increase in positive CSR activities, hence, increasing the performance of corporate governance, may result in higher cost of the firm, and therefore negatively affecting the ROA.

Wholesaler: Between the periods $2000-2008$, social positive had a negative impact on $\operatorname{ROA}(\beta=-0.373$ at $1 \%$ level of significance) which does not support H3. This implies that before 2009, the CSR investment cost outweighs the benefits of doing so in the wholesaler industry (Waddock and Graves, 1997). During 2009 - 2014, social positive is insignificant.

Retailer: Examples of retailer CSR actions include community support and treating employees fairly (Ailawadi et al., 2014), charitable donations, support for schools, cultural, or sports events (Oppewal et al., 2006). Supporting our hypothesis, between the period 2000-2008, social positive activities had a positive impact on $\operatorname{ROA}(\beta=0.107$ and $\beta=0.033$ at $1 \%$ level of significance, respectively). Interestingly, positive environmental activities had a more positive influence on ROA than positive social activities ( $\beta$ $=0.308$ and $\beta=0.055$, respectively). The Shelton Group's 2013 Eco Pulse study (Shelton, 2014) showed that environmental responsibility is more appealing to consumers than socially responsible actions.

Hypothesis 4 (H4): A firm's negative social responsible performance will be negatively related to its financial performance (represented by ROA).

Manufacturer: The negative social activities have a significantly negative impact on the manufacturer's profitability. In particular, the coefficient is equal to -0.210 at $1 \%$ level during the period from $2001-2008$, and equal to -0.202 at $1 \%$ level during the period $2009-2014$. Therefore, H4 is supported by manufacturers.

Negative social activities negatively impact a manufacturer's profit because of decreased employee morale, damaged image as well as violation fines. Negative social activities usually indicate that a manufacturer does not perform its required and/or expected responsibility, which may be associated with financial penalties.

Transportation: Between the periods $2000-2008$, the social negative had a positive impact on $\operatorname{ROA}(\beta=0.091)$ respectively at $1 \%$ level of significance. In the period 2009-2014, the results are similar to the $2000-2008$. Social negative had positive effects on $(\beta=0.026)$. These contradict hypotheses $\mathrm{H} 4$, implying that, negative social activity, if not caught, can affect positive ROA in the short term.

Wholesaler: As concern to $\mathrm{H} 4$, the results between the periods $2000-2008$ and $2009-2014$ show that negative social activities had a negative impact on $\operatorname{ROA}(\beta=-0.219$ 
at $1 \%$ level and $\beta=-0.059$ at $5 \%$ level respectively). In both case hypothesis, $\mathrm{H} 4$ is supported. Moreover, one can conclude that before the market crash of 2008, negative social activities had a higher negative impact on ROA than the period after the market crash $(2009-2014)$.

Retailer: Our hypothesis is not initially supported by the empirical results since negative social CSR activities explain positive ROA, pre-recession. Between the period 2000-2008, social negative activities had a positive impact on ROA $(\beta=0.070)$. However, supporting our hypothesis, between the period $2009-2014$, social negative activities had a negative impact on ROA $(\beta=-0.042)$. Pre-recession, consumers, show resilience to negative social CSR information about the retailer and "any publicity is good publicity". Berger and Sorensen (2010) found that negative publicity could have a positive impact on if the firm is relatively unknown, due to an increase of product awareness. Regarding the effect of word of mouth, Berger and Sorensen (2010) go on to state that "hearing that a friend hated a restaurant should decrease product evaluations, but it should also increase product awareness and accessibility, which may have positive downstream effects on sales."

\subsection{Before Versus After Recession}

Hypothesis 5 (H5): The impact of a firm's positive environmental performance on its profitability changed after the recession in 2009.

Hypothesis 5 is supported by the results of all four industries (Table 4). In particular, the environmental positive coefficient increased by 0.070 from -0.101 to -0.031 at $1 \%$ level of significance. The wholesalers environmental positive coefficient was significant and had positive effects on ROA $(\beta=0.359)$ during the period 20002008 . The coefficient becomes significantly negative $(\beta=$ -0.028 ) during the period $2009-2014$. The change is -0.3868 at $1 \%$ level of significance. The coefficient of the transportation industry increased by 0.0488 from -0.079 to -0030 at $1 \%$ level of significance. The retailers environmental positive coefficient was equal to 0.308 during the period $2000-2008$ and decreased by 0.2529 to 0.055 during the period 2009 - 2014. Note that all industries experienced significant change regarding the impact of positive environmental activities on profitability. However, the changes in the four industries are in different directions. Since the economic recession greatly changed the behaviors of consumers and strategies of many companies, such a dynamic process introduced uncertainty regarding the cost/benefit relationship of positive environmental activities.

For example, for retailers, the change in the impact of CSR environmental activities between 2000 - 2008 compared with $2009-2014$ can be mainly explained by the decrease in consumer responsiveness to environmental CSR initiatives. We examine the impact of the recession (20082009) where consumers are more likely to focus on the value in their purchases (Green and Peloza, 2011), and as a result, we find that ROA decreased for firms. Additional explanations include a result found by (Flammer, 2013) that shows that a company's announcements of CSR initiatives will positively affect its stock price. However, such an impact is less strong if firms have already had more green initiatives.

Hypothesis 6 (H6): The impact of a firm's negative environmental performance on its profitability changed after the recession in 2009.

The hypothesis is supported for the wholesale industry and the retail industry which had a significant change in preand post-recession results (Table 4). In particular, for the wholesale industry, the coefficient for negative environmental activities changed from -0.451 to -0.099 by

0.3521 at $1 \%$ level of significance. For the retail industry, $\beta$ changed from -0.568 to -0.081 by

0.4874 at $1 \%$ level of significance. The changes indicate that the wholesaler and retailer's negative environmental activities become less influential when comparing the period $2009-2014$ to the period $2000-2008$. These reduced impacts are likely due to more value-sensitive behaviors and purchases of consumers after the recession (Green and Peloza, 2011).

Hypothesis 7 (H7): The impact of a firm's positive social performance on its profitability changed after the recession in 2009.

Hypothesis 7 is supported by all industries, except for transportation (Table 4). In particular, the coefficient for the manufacturing industry decreased from 0.286 to -0.060 by 0.3282 at $1 \%$ level of significance. For the wholesale industry, $\beta$ increased by 0.3778 at $1 \%$ level of significance when comparing the period 2000-2008 to the period 2009-2014. The retailer's positive social coefficient becomes significantly less influential when comparing the period 2009-2014 $(\beta=0.033)$ compared to the period 2000 $-2008(\beta=0.107)$ at $1 \%$ level of significance.

Similar to what we observed for the positive environmental activities, the changes in the industries are in different directions, which are likely the results of the economic uncertainty, changing consumer behaviors, and changing business strategies caused by the recession.

Hypothesis 8 (H8): The impact of a firm's negative social performance on its profitability changed after the recession in 2009.

Hypothesis 8 is supported by all industries except for the manufacturing industry (Table 4). For the wholesale industry, the coefficient changed from -0.219 to -0.059 by 0.1604 at $1 \%$ level of significance. For the transportation industry, regarding the change between the periods 2000-2008 and 2009 - 2014, negative social activities experience a significant change from a positive impact on ROA to a smaller positive impact on ROA $(\beta=0.090$ and $\beta$ $=0.026$, respectively), yet for the retailer, negative social activities experience a significant change from a positive impact on ROA to a negative impact on $\operatorname{ROA}(\beta=0.070$ and $\beta=-0.042$, respectively). The mixed direction of changes once again indicates the dynamics of interactions among consumer behaviors, business strategy, and economic uncertainty. 
Table 4 Test results for hypothesis 5-8

\begin{tabular}{|c|c|c|c|c|}
\hline ENV POS & Manufacturer & Wholesaler & Transportation & Retailer \\
\hline \multirow{4}{*}{$\beta A F-\beta B F$} & $0.07^{*}$ & $-0.3868^{*}$ & $0.0488^{*}$ & $-0.2529^{*}$ \\
\hline & $0.0165^{\star *}$ & $0.3521^{* *}$ & $-0.0203^{* *}$ & $0.4874^{* *}$ \\
\hline & $-0.3282^{* * *}$ & $0.3778^{* * *}$ & $-0.0291^{* * *}$ & $-0.0744^{* * *}$ \\
\hline & $0.0079^{* * * *}$ & $0.1604^{* * * *}$ & $-0.0634^{\star * * *}$ & $-0.1119^{* * * *}$ \\
\hline \multirow{4}{*}{$\beta_{B F} S t d E r r$} & $0.0092^{*}$ & $0.1228^{*}$ & $0.0127^{*}$ & $0.041^{*}$ \\
\hline & $0.0105^{\star *}$ & $0.0755^{\star *}$ & $0.009^{* *}$ & $0.0844^{\star *}$ \\
\hline & $0.0124^{* * *}$ & $0.1366^{* * *}$ & $0.0154^{* * *}$ & $0.0308^{* * *}$ \\
\hline & $0.0046^{* * * *}$ & $0.0637^{* * * *}$ & $0.0111^{* * * *}$ & $0.0194^{* * * *}$ \\
\hline \multirow{4}{*}{$\beta_{A F} S t d E r r$} & $0.0027^{*}$ & $0.0134^{*}$ & $0.0045^{*}$ & $0.0102^{*}$ \\
\hline & $0.0081^{* *}$ & $0.0496^{* *}$ & $0.0074^{* *}$ & $0.0207^{* *}$ \\
\hline & $0.0023^{* * *}$ & $0.0145^{\star * *}$ & $0.005^{* * *}$ & $0.0096^{* * *}$ \\
\hline & $0.0052^{* * * *}$ & $0.0251^{* * * *}$ & $0.0091^{* * * *}$ & $0.0107^{* * * *}$ \\
\hline \multirow{4}{*}{$\begin{array}{l}\text { Standard Error } \\
\text { of } \beta A F-\beta B F\end{array}$} & $0.0096^{*}$ & $0.1235^{*}$ & $0.0135^{*}$ & $0.0423^{*}$ \\
\hline & $0.0133^{* *}$ & $0.0903^{* *}$ & $0.0117^{\star *}$ & $0.0869^{* *}$ \\
\hline & $0.0126^{* * *}$ & $0.1373^{* * *}$ & $0.0162^{* * *}$ & $0.0323^{* * *}$ \\
\hline & $0.0069^{* * * *}$ & $0.0684^{* * * *}$ & $0.0143^{* * * *}$ & $0.0221^{* * * *}$ \\
\hline \multirow{4}{*}{$Z$} & $7.2986^{\star}$ & $-3.1322^{*}$ & $3.6124^{*}$ & $-5.9839^{*}$ \\
\hline & $1.2423^{\star *}$ & $3.8975^{\star *}$ & $-1.7453^{* *}$ & $5.6107^{\star *}$ \\
\hline & $-26.0605^{\star * *}$ & $2.7514^{\star * *}$ & $-1.8019^{* * *}$ & $-2.3019^{* * *}$ \\
\hline & $-5.0551^{\text {****}}$ & $2.3429^{* * * *}$ & $-4.4231^{\text {**** }}$ & $-5.0551^{* * * *}$ \\
\hline \multirow{4}{*}{$P$} & $0.0000^{*}$ & $0.0019^{*}$ & $0.0003^{*}$ & $0.0000^{*}$ \\
\hline & $0.2142^{* *}$ & $0.0001^{* *}$ & $0.0811^{* *}$ & $0.0000^{* *}$ \\
\hline & $0.0000^{* * *}$ & $0.0063^{* * *}$ & $0.0718^{* * *}$ & $0.0215^{\star * *}$ \\
\hline & $0.2547^{\star * * *}$ & $0.0197^{\star * * *}$ & $0.0000^{* * * *}$ & $0.0000^{* * * *}$ \\
\hline
\end{tabular}

${ }^{*}$ Hypothesis 5 results, ${ }^{* *}$ Hypothesis 6 results, ${ }^{* * *}$ Hypothesis 7 results, ${ }^{* * * *}$ Hypothesis 8 results

\section{DISCUSSION AND MANAGERIAL IMPLICATIONS}

Our paper provides important management implications for supply chain firms as well as policymakers. The literature has shown mixed results regarding the impacts of CSR on the financial performances of companies (McWilliams and Siegel, 2000). Our findings echo the literature and demonstrate that the firms at different stages of the supply chain may experience different impacts of CSR activities.

First, positive environmental and social activities have mostly negative impacts on the short-term profits of most supply chain industries except for retailers. These results indicate that manufacturers, wholesalers, and firms in the transportation industry may consider CSR activities as investments which incur short-term losses in exchange for long-term benefits (Bansal, 2005, Branco and Rodrigues, 2006). The firms could invest in CSR as insurance that could mitigate potential future risks (Klein and Dawar, 2004; Peloza, 2006; Godfrey et al., 2009) or as a real option that could allow them to capture future opportunities (Husted, 2005; Cassimon et al., 2016). Therefore, the short-term loss can be justified as either insurance cost or option premium.

In contrast, the retailers' positive environmental and social activities have positive impacts on their short-term profits. It is well known that CSR can positively affect reputation, brand images and customer loyalty (Porter and Kramer, 2006; He and Lai, 2014). Since retailers are the supply chain members who have direct contact with consumers their reputation and brand images are especially important. Our results indicate that the benefits of their positive CSR efforts can outweigh the cost even in the shortterm.

Second, research in the literature has suggested that CSR activities cause asymmetrically larger damages to the companies compared with the benefits from positive CSR activities (Sen and Bhattacharya, 2001; Klein and Dawar, 2004). Our results also indicate an asymmetrical relationship for environmental CSR activities. In particular, for all four supply chain industries, while positive environmental activities have mixed impacts negative environmental activities are always associated with negative financial performances. Therefore, supply chain firms should avoid negative environmental activities. Conducting such activities may result in damaged brand images, legal problems, and financial penalties.

Third, negative social activities have mixed financial impacts on supply chain firms. In particular, for the transportation and retail industry, conducting negative social activities may lead to financial benefits. The results suggest that the current policies and regulations be revised or better reinforced for these industries so that the financial incentives of conducting negative social activities are eliminated.

Fourth, for many industries, the financial impacts of the CSR activities on supply chain firms have changed since the financial crisis in 2008. However, due to the economic uncertainty caused by the global recession, the directions of changes are mixed depending on the industries and CSR activities. Therefore, supply chain firm managers should be cautious when they invest in CSR activities as a business 
strategy while policymakers should ensure that policies and regulations can reflect changes in supply chain industries.

\section{CONCLUSION AND FUTURE RESEARCH}

This research investigates the impacts of corporate social responsibility (CSR) activities on supply chain firms' financial performances. We considered four supply chainrelated industries: manufacturer, transportation, wholesaler, and retailer during both pre and post-recession periods.

Our empirical study showed that only the retailer's positive environmental and social activities consistently have positive impacts on financial performances. For the other supply chain industries, the positive environmental and social activities either have negative or mixed impacts on their financial performances. The negative environmental activities, in turn, have negative impacts on the financial performances of all four industries. The impacts of negative social activities, however, are mixed and depend on the industries and the time period. Our results also indicate that the financial impacts of the CSR activities on the supply chain firms have changed after the 2008 economic recession. The directions of the changes are mixed and depend on the industry and the type of activities.

One of the limitations of this research is a lack of consistent data on $R \& D$ intensity and marketing intensity across all industries (manufacturer, retailer, wholesaler, and transportation) included in our study. We considered $R \& D$ intensity (Acquaah and Chi, 2007) and marketing intensity (Callan and Thomas, 2009). These control variables, however, were not significant. When considering these control variables, most of the data were eliminated from the analysis because many of the firms in the Retailer, Transportation, and Wholesaler industries do not undertake $R \& D$ activities. Moreover, when concerning marketing intensity, we also saw a few companies conducting this activity in Manufacturer and Transportation Industries. Therefore, for consistency across all industries, we only consider firm size, capital intensity, industry type, and year as control variables.

For future research, we will study the difference in CSR activity and behavior within firms and across countries (Maignan and Ralston, 2002). We also plan to include the influence of sector type for each industry (Elg and Hultman, 2011).

\section{REFERENCES}

Acquaah, M., and Chi, T. (2007). A longitudinal analysis of the impact of firm resources and industry characteristics on firm-specific profitability. Journal of Manage Governance 11 (3), pp. 179-213.

Ailawadi, K., Neslin, S., Luan, Y., and Taylor, G. (2014). Does retailer CSR enhance behavioral loyalty? A case for benefit segmentation. International Journal of Research in Marketing 31 (2), pp. 156-167.

Andersen, M., and Skjoett-Larsen, T. (2009). Corporate social responsibility in global supply chains. Supply Chain Management: An International Journal 14 (2), pp. 75-86.

Banerjee, S.B., Iyer, E.S., and Kashyap, R.K. (2003). Corporate environmentalism: Antecedents and influence of industry type. Journal of Marketing 67 (2), pp. 106-122.
Bansal, P. (2005). Evolving Sustainability: A longitudinal study of corporate sustainable development. Strategic Management Journal 26 (3), pp. 197-218.

Barnett, M.L. (2007). Stakeholder influence capacity and the variability of financial returns to corporate social responsibility. Academy Management Review 32 (3), pp. 794-816.

Bauman, C.W., and Skitka, L.J. (2012). Corporate social responsibility as a source of employee satisfaction. Research in Organizational Behavior 32 (3), pp. 63-86.

Becchetti, L., Ciciretti, R., and Hasan, I. (2007). Corporate social responsibility and shareholders value: an event study analysis. Working paper, Federal reserve Bank of Atlanta.

Berger, J., Sorensen, A.T., and Rasmussen, S. (2010). Positive effects of negative publicity: when negative reviews increase sales. Marketing Science 29, pp. 815-827.

Berman, S.L., Wicks, A.C., Kotha, S.K., and Jones, T.M. (1999). Does stakeholder orientation matter? the relationship between stakeholder management models and firm financial performance. Academy Management Journal 42 (5), pp. $488-506$.

Blombck, A., and Wigren, C. (2008). Challenging the importance of size as determinant for csr activities. Management of Environmental Quality: An International Journal 20 (3), pp. 255-270.

Bowen, F.E., Cousins, P.D., Lamming, R.C., and Faruk, A.C. (2006). Horses for courses: Explaining the gap between the theory and practice of green supply. In: Sarkis J. (eds) Greening the Supply Chain, pp. 151-172, Springer, London.

Brammer, S., Brooks, C., and Pavelin, S. (2005). corporate social performance and stock returns: uk evidence from disaggregate measures. Financial Management 35 (3), pp. 97-116.

Branco, M.C., and Rodrigues, L.L. (2006). Corporate social responsibility and resource-based perspectives. Journal of Business Ethics 69 (2), pp. 111-132.

Brown, T.J., and Dacin, P.A. (1997). The company and the product: corporate associations and consumer product responses. Journal of Marketing 61 (1), pp. 68-84.

Burke, L., Logsdon, J., Mitchell, W., Reiner, M., and Vogel, D. (1986). Corporate community involvement in the San Francisco bay area. California Management Review 28 (3), pp. 122-141.

Burt, S., Johansson, U., \& Thelander, ^̊. (Eds.) (2010). Consuming IKEA, Different perspectives on consumer images of a global retailer. (Lund Studies in Economics and management 118). Lund Business Press.

Callan, S., and Thomas, J. (2009). Corporate financial performance and corporate social performance: An update and reinvestigation. Corporate Social Responsibility and Environmental Management 16 (2), pp. 61-78.

Carroll, A.B. (1979). A three-dimensional conceptual model of corporate performance. Academy of Management Review 4 (4), pp. 497-505.

Carroll, A.B., and Shabana, K.M. (2010). The business case for corporate social responsibility: A review of concepts, research and practice. International Journal of Management Reviews 12 (1), pp. 85-105.

Carter, C.R., and Jennings, M.M. (2002). Logistics social responsibility: An integrative framework. Journal of Business Logistics 23 (1), pp. 145-180.

Cassimon, A., Engelen, P., and Liedekerke, L.V. (2016). When do firms invest in corporate social responsibility? a real option framework. Journal of Business Ethics 137 (1), pp. 15-29.

Cho, E., and Park, H. (2015). Is CSR really profitable? Evidence from Korea. Journal of Applied Business Research 31 (6), pp. 2167-2186.

Choi, J.S., Kwak, Y.M., and Choe, C. (2010). Corporate social responsibility and corporate financial performance: 
Evidence from Korea. Australian Journal of Management 35 (3), pp. 291-311.

Christopher, M. (2005), Logistics and Supply Chain Management. Strategies for Reducing Cost and Improving Service, 3rd ed., Financial Times Pitman Publishing, London.

Cochran, P.L., and Wood, R.A. (1984). Corporate social responsibility and financial performance. The Academy of Management Journal 27 (1), pp. 42-56.

Cowen, S., Ferreri, L., and Parker, L. (1987). The impact of corporate characteristics on social responsibility disclosure: A typology and frequency-based analysis. Accounting. Organization and Society 12 (2), pp. 111-122.

Decambre, M. (2019). Nobel-winning economist Krugman warns that a U.S. recession looms in 2019, marketwatch.com (Published: Feb 11, 2019 1:54 p.m. ET). URL: https://www.marketwatch.com/story/nobel-winningeconomist-krugman-warns-that-a-us-recession-looms-in2019-2019-02-11

Despeisse M., Ball P.D., and Evans S. (2012). Modelling and Tactics for Sustainable Manufacturing: An Improvement Methodology. In: Seliger G. (eds) Sustainable Manufacturing, pp. 9-16, Springer, Berlin, Heidelberg.

Ding, D., Ferreira, C., and Wongchoti, U. (2018). Reading between the lines: not all CSR is good CSR. Pacific Accounting Review 30 (3), pp. 318-333.

DOC, (2014). How does Commerce define Sustainable Manufacturing? Technical Report. International Trade Administration. U.S. Department of Commerce.

Dovi, V., Friedler, F., Huisingh, D., and Klemes, J. (2009). Cleaner energy for sustainable future. Journal of Cleaner Production 17 (10), pp. 889-895.

Elg, U., and Hultman, J. (2011). Retailers management of corporate social responsibility (csr) in their supplier relationships does practice follow best practice? The International Review of Retail, Distribution and Consumer Research 21 (5), pp. 445-460.

Elkington, J. (1997), Cannibals with Forks. The Triple Bottom Line of 21 st Century Business, Capstone, Oxford.

Ellen, P., Webb, D., and Mohr, L. (2006). Building corporate associations: Consumer attributions for corporate socially responsible programs. Journal of the Academy of Marketing Science 34 (2), pp. 147-157.

Ellis, L., and Bastin, C. (2011). Corporate social responsibility in times of recession: Changing discourses and implications for policy in practice. Corporate Social Responsibility and Environmental Management 19 (5), pp. 294-305.

Fama, E.F., and French, K.R. (2000). Forecasting profitability and earnings. Journal of Business 73 (2), 161-175.

Feldman, S.J., Soyka, P.A., and Ameer, P.G. (1997). Does improving a firm's environmental management system and environmental performance result in a higher stock price? The Journal of Investing 6 (4), pp. 87-97.

Flammer, C. (2013). Corporate social responsibility and shareholder reaction: The environmental awareness of investors. Academy of Management Journal 56 (3), pp. $758-781$.

Flammer, C. (2015). Does corporate social responsibility lead to superior financial performance? a regression discontinuity approach. Management Science 61 (11), pp. 2549-2568.

Fombrun, C.J. (2005), Corporate reputation as economic assets. In: Hitt, M.A, Freeman E.R, and Harrison, J.S. (eds) The Blackwell Handbook of Strategic Management. Blackwell Publishers, Malden.

Fombrun, C.J., Gardberg, N.A., and Barnett, M.L. (2000). Opportunity platforms and safety nets: Corporate reputation and reputational risk. Business Society Review 105 (1), pp. 85-106.

Galema, R., Plantinga, A., and Scholtens, B. (2008). The stocks at stake: Return and risk in socially responsible investment. Journal of Banking and Finance 32 (12), pp. 2646-2654.
Gallo, P., and Jones-Christensen, L. (2011). Firm size matters: An empirical investigation of organizational size and ownership on sustainability-related behaviors. Business and Society 50 (2), pp. 315-349.

Ghosh, D., and Wu, A. (2007). Intellectual capital and capital markets: additional evidence. Journal of Intellectual Capital 8 (2), pp. 216 - 235.

Godfrey, P., Merrill, C., and Hansen, J. (2009). The relationship between corporate social responsibility and shareholder value: An empirical test of the risk management hypothesis. Strategic Management Journal 30 (4), pp. 425-445.

Green, T., Peloza, J. (2011). How does corporate social responsibility create value for consumers? Journal of Consumer Marketing 28 (1), pp. 48-56.

Haapal, K., Zhao, F., Camelio, J., Sutherland, J., Skerlos, S., Dornfeld, D., Jawahir, H., Clarens, A., and Rickli J.L. (2013). A review of engineering research in sustainable manufacturing. Journal of Manufacturing Science and Engineering 135 (4), 041013.

Handelman, J., Arnold, S. (1999). The role of marketing actions with a social dimension: Appeals to the institutional environment. Journal of Marketing 63 (3), pp. 33-48.

Handfield, R., Sroufe, S., and Walton, S. (2005). Integrating environmental management and supply chain strategies. Business Strategy and the Environment 14 (1), 1, pp. 1-19.

Harjoto, M.A., and Jo, H. (2011). Corporate governance and CSR nexus. Journal of Business Ethics 100 (1), pp. 45-67.

Harrison, J.S., and Freeman, R.E. (1999). Stakeholders, social responsibility, and performance: Empirical evidence and theoretical perspectives. Academy Management Journal 42 (5), pp. 479-485.

Heal, G. (2005). Corporate social responsibility: An economic and financial framework. Geneva Papers on Risk \& Insurance Issues \& Practice 30 (3), pp. 387-409.

He, Y., and Lai, K. (2014). The effect of corporate social responsibility on brand loyalty: the mediating role of brand image. Total Quality Management \& Business Excellence 25 (3-4), pp. 249-263.

Homburg, C., Stierl, M., Bornemann, T., 2013. Corporate social responsibility in business-to-business markets: How organizational customers account for supplier corporate social responsibility engagement. Journal of Marketing 77, 54-72.

Husted, B.W., (2005). Risk Management, Real Options, and Corporate Social Responsibility. Journal of Business Ethics 60 (2), pp. 175-183.

Jang, J., and Choi, H. (2010). The relation between corporate social responsibility and financial performance. Korean Journal of Business Administration 23 (2), pp. 633-649.

Klein, J., Dawar, N. (2004). Corporate social responsibility and consumers' attributions and brand evaluations in a productharm crisis. International Journal of Research in Marketing 21 (3), pp. 203-217.

Koplin, J., Seuring, S., and Mesterharm, M. (2007). Incorporating sustainability into supply management in the automotive industry - the case of the Volkswagen AG. Journal of Cleaner Production 15 (11-12), pp.1053-1062.

Laroche, M., Bergeron, J., and BarbaroForleo, G. (2001). Targeting consumers who are willing to pay more for environmentally friendly products. Journal of Consumer Marketing 18 (6), pp. 503-520.

Lee, H.C.B., Cruz, J.M., and Shankar, R. (2018). Corporate social responsibility (CSR) issues in supply chain competition: Should greenwashing be regulated? Decision Sciences 49 (6), pp. 1088-1115.

Lewis, S. (2001). Measuring Corporate Reputation. Corporate Communications: An International Journal 6 (1), pp. 3135. 
Linton, J., Klassen, R., and Jayaraman, V. (2007). Sustainable supply chains: An introduction. Journal of Operations Management 25 (6), pp. 1075-1082.

Luo, X., and Bhattacharya, C., (2006). Corporate social responsibility, customer satisfaction, and market value. Journal of Marketing 70 (4), pp. 1-18.

Maignan, I., and Ralston, D. (2002). Corporate social responsibility in Europe and the U.S.: Insights from businesses selfpresentations. Journal of International Business Studies 33 (3), pp. 497-514.

Maloni, M. and Brown, M. (2006), Corporate Social Responsibility in the Supply Chain: An Application in the Food Industry, Journal of Business Ethics, 68(1), 35-62.

McGoldrick, P., and Freestone, O. (2008). Ethical product premiums: Antecedents and extent of consumers willingness to pay. The International Review of Retail, Distribution and Consumer Research 18 (2), pp. 185-201.

McGuire, J.B., Sundgren, A., and Schneeweis, T., (1988). Corporate social responsibility and firm financial performance. Academy of Management Journal 31 (4), pp. 854-872.

McWilliams, A., and Siegel, D. (2000). Corporate social responsibility and financial performance: Correlation or misspecification? Strategic Management Journal 21 (5), pp. 603-609.

McWilliams, A., Siegel, D., (2001). Corporate social responsibility: A theory of the firm perspective. The Academy of Management Review 26 (1), pp. 117-127.

Montgomery, D. C., Peck, E. A. and Vining, G. G. (2001). Introduction to Linear Regression Analysis. 3rd Edition, New York, New York: John Wiley \& Sons.

Moore, G. (2001). Corporate social and financial performance: An investigation in the U.K. supermarket industry. Journal of Business Ethics 34 (3-4), pp. 299-315.

Murphy, P., Smith, J.E., and Daley, J.M. (1991). Ethical behavior of U.S. general freight carriers: An empirical assessment. Logistics and Transportation Review 27 (1), pp. 55-65.

Murphy, P.R., and Daley, J.M., (1990). Ethical issues and behavior in the LTL motor carrier industry. Transportation Journal 30 (1), pp. 20-29.

Mwangi, C., and Oyenje, J. (2013). The relationship between corporate social responsibility practices and financial performance of firms in the manufacturing, construction and allied sector of the Nairobi securities exchange. International Journal of Business, Humanities and Technology 3 (2), pp. 81-90.

Oppewal, H., Alexander, A., and Sullivan, P. (2006). Consumer perceptions of corporate social responsibility in town shopping centres and their influence on shopping evaluations. Journal of Retailing and Consumer Services 13 (4), 261-274.

Pedersen, E.R. and Andersen, M. (2006), Safeguarding Corporate Social Responsibility (CSR) in Global Supply Chains: How Codes of Conduct are Managed in Buyer Supplier Relationships. Journal of Public Affairs, 6 (3-4), pp. 228240.

Peloza, J. (2006). Using corporate social responsibility as insurance for financial performance. California Management Review 48 (2), pp. 52-72.

Perry, P., and Towers, N. (2009). Determining the antecedents for a strategy of corporate social responsibility by small- and medium-sized enterprises in the UK fashion apparel industry. Journal of Retailing and Consumer Services 16 (5), pp. 377-385.

Placier, K. (2011). The impact of recession on the implementation of corporate social responsibility in companies. Journal of Competitiveness 3 (2), pp. 83-98.

Porter, M.E., and Kramer, M.R. (2006). The link between competitive advantage and corporate social responsibility. Harvard Business Review 84 (12), pp. 78-90.
Prior, D., Surrroca, J., Tribo, J.A., 2008. Are socially responsible managers really ethical? exploring the relationship between earnings management and corporate social responsibility. Corporate Governance: An International Review 16 (3), pp. 160-177.

Quelch, J.A., and Jocz, K.E. (2009). How to market in a downturn. Harvard Business Review 87 (4), pp. 52-62.

Razafindrambinina, D., and Sabran, A., (2014). The impact of strategic corporate social responsibility on operating performance: An investigation using data envelopment analysis in Indonesia. Journal of Business Studies Quarterly 6 (1), pp. 68-78.

Russo, M., and Fouts, P. (1997). A resource-based perspective on corporate environmental performance and profitability. Academy of Management Journal 40 (3), pp. 534-559.

Saiia, D.H., Carroll, A.B., and Buchholtz, A.K. (2003). Philanthropy as strategy: When corporate charity begins at home. Business \& Society 42 (2), pp.169-201.

Sakunasingha, B., Jiraporn, P., and Uyar, A. (2018). Which CSR activities are more consequential? Evidence from the Great Recession. Finance Research Letters 27, pp. 161-168.

Sen, S., and Bhattacharya, C. B. (2001). Does doing good always lead to doing better? Consumer reactions to corporate social responsibility. Journal of Marketing Research 38 (2), pp. 225-243.

Servaes, H., and Tamayo, A., (2013). The impact of corporate social responsibility on firm value: The role of customer awareness. Management. Science 59 (5), pp. 1045-1061.

Seuring, S., and Mller, M. (2008). From a literature review to a conceptual framework for sustainable supply chain management. Journal of Cleaner Production 16 (5), pp. 1699-1710.

Shelton, S., 2014. Environmental responsibility vs. social responsibility: Which ones the winning approach? Shelton Group. URL: https://sheltongrp.com/posts/environmentalresponsibility-vs-social-responsibility-ones-winningapproach/

Shen, C.H., and Chang, Y. (2008). Ambition versus conscience, does corporation social responsibility pay off? the application of matching methods. Journal of Business Ethics 88 (Suppl 1), 133-153.

Srinivasan, R., Rangaswamy, A., \& Lilien, G. L. (2005). Turning adversity into advantage: Does proactive marketing during a recession pay off? International Journal of Research in Marketing 22(2), pp. 109-125.

Stanwick, P.A., and Stanwick, S.D. (1998). The relationship between corporate social performance, and organization size, financial performance, and environmental performance: An empirical examination. Journal of Business Ethics 17 (2), pp. 195-204.

Surroca, J., Tribo, J.A., and Waddock, S. (2010). Corporate responsibility and financial performance: The role of intangible resources. Strategic Management Journal 31 (5), pp. 463-490.

Udayasankar, K. (2008). Corporate social responsibility and firm size. Journal of Business Ethics 83 (2), pp. 167-175.

Visser, W., Matten, D., Pohl, M., Tolhurst, N., Bohmer, K., Ghebremariam, A., Hennigfeld, J., Huble, S.S. (2008). The A to $Z$ of Corporate Social Responsibility: A Complete Reference Guide to Concepts, Codes and Organisations. Wiley.

Waddock, S.A., and Graves, S.B. (1997). The corporate social performance financial performance link. Strategic Management Journal 18 (4), pp. 303-319.

Wagner, T., Bicen, P., and Hall, Z. (2008). The dark side of retailing: Towards a scale of corporate social irresponsibility. International Journal of Retail \& Distribution Management 36 (2), pp. 124-142.

Walmart. (2018). 2018 Global Responsibility Report. URL: https://corporate.walmart.com/media- 
library/document/2018-grr-

summary/_proxyDocument?id=00000162-e4a5-db25-a97f$\mathrm{f} 7 \mathrm{fd} 785 \mathrm{a} 0001$

Wang, H., Choi, J., and Li, J. (2008). Too little or too much? untangling the relationship between corporate philanthropy and firm financial performance. Organization Science 19 (1), pp. $143-159$.

Welch, S. (2009). Corporate social responsibility in a recession. Bloomberg https://www.bloomberg.com/news/articles/2009-05-

20/corporate-social-responsibility-in-a-recession

Wilhelm, M.M., Blome, C., Bhakoo, V., and Paulraj, A. (2016). Sustainability in multi-tier supply chains: Understanding the double agency role of the first-tier supplier. Journal of Operations Management 41, pp. 42-60.

Zadek, S. (2000). Ethical Trade Futures. New Economics Foundation, London. 


\section{APPENDIX}

Table 5 Test results for hypotheses 1-4

\begin{tabular}{|c|c|c|c|c|c|c|c|c|}
\hline \multirow[b]{2}{*}{ Period } & \multicolumn{2}{|c|}{$\begin{array}{l}\text { Manufacturer } \\
\text { (SIC 2000-3999) }\end{array}$} & \multicolumn{2}{|c|}{$\begin{array}{l}\text { Transportation } \\
\text { (SIC 4000-4999) }\end{array}$} & \multicolumn{2}{|c|}{$\begin{array}{c}\text { Wholesaler } \\
\text { (SIC 5000-5199) }\end{array}$} & \multicolumn{2}{|c|}{$\begin{array}{c}\text { Retailer } \\
\text { (SIC 5200-5999) }\end{array}$} \\
\hline & $2000-2008$ & $2009-2014$ & $2000-2008$ & $2009-2014$ & $2000-2008$ & $2009-2014$ & $2000-2008$ & $2009-2014$ \\
\hline $\mathrm{n}$ & 4627 & 4897 & 1101 & 1150 & 302 & 356 & 885 & 894 \\
\hline Constant & $\begin{array}{l}0.337^{* *} \\
(0.002)\end{array}$ & $\begin{array}{l}0.325^{* *} \\
(0.000)\end{array}$ & $\begin{array}{l}0.299 * * \\
(0.003)\end{array}$ & $\begin{array}{l}0.241^{* *} \\
(0.002)\end{array}$ & $\begin{array}{l}0.383^{* *} \\
(0.021)\end{array}$ & $\begin{array}{l}0.371^{* *} \\
(0.006)\end{array}$ & $\begin{array}{l}1.048^{* *} \\
(0.010)\end{array}$ & $\begin{array}{l}0.891^{* *} \\
(0.004)\end{array}$ \\
\hline I.ENVpos & $\begin{array}{l}-0.101^{* *} \\
(0.009)\end{array}$ & $\begin{array}{l}-0.031^{* *} \\
(0.003)\end{array}$ & $\begin{array}{l}-0.079^{* *} \\
(0.013)\end{array}$ & $\begin{array}{l}-0.030^{* *} \\
(0.005)\end{array}$ & $\begin{array}{l}0.359^{* *} \\
(0.123)\end{array}$ & $\begin{array}{l}-0.028^{*} \\
(0.013)\end{array}$ & $\begin{array}{l}0.308^{* *} \\
(0.041)\end{array}$ & $\begin{array}{l}0.055^{\star *} \\
(0.010)\end{array}$ \\
\hline I.ENVneg & $\begin{array}{l}-0.247^{* *} \\
(0.010)\end{array}$ & $\begin{array}{l}-0.231^{* *} \\
(0.008)\end{array}$ & $\begin{array}{l}-0.119^{* *} \\
(0.009)\end{array}$ & $\begin{array}{l}-0.139 * * \\
(0.007)\end{array}$ & $\begin{array}{l}-0.451^{* *} \\
(0.076)\end{array}$ & $\begin{array}{l}-0.099^{*} \\
(0.050)\end{array}$ & $\begin{array}{l}-0.568^{* *} \\
(0.084)\end{array}$ & $\begin{array}{l}-0.081^{* *} \\
(0.021)\end{array}$ \\
\hline I.SOCpos & $\begin{array}{l}0.268^{* *} \\
(0.012)\end{array}$ & $\begin{array}{c}-0.06 \\
(0.002)\end{array}$ & $\begin{array}{l}-0.038^{*} \\
(0.015)\end{array}$ & $\begin{array}{l}-0.067^{* *} \\
(0.005)\end{array}$ & $\begin{array}{l}-0.373^{\star *} \\
(0.137)\end{array}$ & & $\begin{array}{l}0.107^{* *} \\
(0.031)\end{array}$ & $\begin{array}{l}0.033^{* *} \\
(0.010)\end{array}$ \\
\hline I.SOCneg & $\begin{array}{l}-0.210^{* *} \\
(0.005)\end{array}$ & $\begin{array}{l}-0.202^{* *} \\
(0.005)\end{array}$ & $\begin{array}{l}0.090^{* *} \\
(0.011)\end{array}$ & $\begin{array}{l}0.026^{* *} \\
(0.009)\end{array}$ & $\begin{array}{l}-0.219^{\star *} \\
(0.064)\end{array}$ & $\begin{array}{l}-0.059^{*} \\
(0.025)\end{array}$ & $\begin{array}{l}0.070^{* *} \\
(0.019)\end{array}$ & $\begin{array}{l}-0.042^{* *} \\
(0.011)\end{array}$ \\
\hline 2002 & $\begin{array}{l}-0.023^{* *} \\
(0.002)\end{array}$ & & $\begin{array}{l}0.021^{* *} \\
(0.010)\end{array}$ & & & & & \\
\hline 2003 & $\begin{array}{l}-0.020^{* *} \\
(0.002)\end{array}$ & & $\begin{array}{l}0.024^{* *} \\
(0.002)\end{array}$ & & & & $\begin{array}{l}0.011^{*} \\
(0.005)\end{array}$ & \\
\hline 2004 & $\begin{array}{l}-0.009 * * \\
(0.002)\end{array}$ & & $\begin{array}{l}0.023^{* *} \\
(0.002)\end{array}$ & & & & & \\
\hline 2005 & & & $\begin{array}{l}0.024^{* *} \\
(0.003)\end{array}$ & & & & & \\
\hline 2006 & & & $\begin{array}{l}0.033^{* *} \\
(0.003)\end{array}$ & & & & $\begin{array}{l}0.016^{* *} \\
(0.005)\end{array}$ & \\
\hline 2007 & & & $\begin{array}{l}0.041^{* *} \\
(0.003)\end{array}$ & & & & $\begin{array}{l}0.013^{*} \\
(0.006)\end{array}$ & \\
\hline 2008 & $\begin{array}{l}0.010^{* *} \\
(0.003)\end{array}$ & & $\begin{array}{l}0.042^{* *} \\
(0.003)\end{array}$ & & & & & \\
\hline 2010 & & $\begin{array}{l}0.033^{* *} \\
(0.000)\end{array}$ & & $\begin{array}{l}0.006^{* *} \\
(0.000)\end{array}$ & & $\begin{array}{l}-0.009^{* *} \\
(0.003)\end{array}$ & & $\begin{array}{l}0.013^{* *} \\
(0.001)\end{array}$ \\
\hline 2011 & & $\begin{array}{l}0.041^{* *} \\
(0.001)\end{array}$ & & & & & & $\begin{array}{l}0.016^{* *} \\
(0.002)\end{array}$ \\
\hline 2012 & & $\begin{array}{l}0.027^{* *} \\
(0.001)\end{array}$ & & $\begin{array}{l}0.006^{* *} \\
(0.002)\end{array}$ & & & & $\begin{array}{l}0.028^{* *} \\
(0.002)\end{array}$ \\
\hline 2013 & & $\begin{array}{l}-0.021^{* *} \\
(0.001)\end{array}$ & & & & $\begin{array}{l}-0.017^{* *} \\
(0.006)\end{array}$ & & $\begin{array}{l}0.024^{* *} \\
(0.003)\end{array}$ \\
\hline 2014 & & $\begin{array}{l}-0.010^{* *} \\
(0.001)\end{array}$ & & & & $\begin{array}{l}-0.013^{*} \\
(0.006)\end{array}$ & & $\begin{array}{l}0.025^{* *} \\
(0.003)\end{array}$ \\
\hline $\mathrm{Cl}$ & $\begin{array}{l}-0.000^{* *} \\
(0.000)\end{array}$ & $\begin{array}{l}-0.000^{* *} \\
(0.000)\end{array}$ & $\begin{array}{l}-0.049^{* *} \\
(0.001)\end{array}$ & $\begin{array}{l}-0.007^{* *} \\
(0.000)\end{array}$ & $\begin{array}{l}-0.000^{*} \\
(0.000)\end{array}$ & $\begin{array}{l}-0.010^{* *} \\
(0.002)\end{array}$ & $\begin{array}{c}-0.646^{* *} \\
(0.011)\end{array}$ & $\begin{array}{c}-0.368^{* *} \\
(0.007)\end{array}$ \\
\hline LogEMP & $\begin{array}{l}0.024^{* *} \\
(0.000)\end{array}$ & $\begin{array}{l}0.031^{* *} \\
(0.000)\end{array}$ & $\begin{array}{c}-0.010^{* *} \\
(0.001)\end{array}$ & $\begin{array}{l}-0.009^{* *} \\
(0.001)\end{array}$ & $\begin{array}{l}0.029^{* *} \\
(0.006)\end{array}$ & $\begin{array}{l}0.028^{* *} \\
(0.003)\end{array}$ & $\begin{array}{l}-0.024^{* *} \\
(0.001)\end{array}$ & $\begin{array}{c}-0.023^{* *} \\
(0.001)\end{array}$ \\
\hline
\end{tabular}

Note: ${ }^{*} p<.05 ;{ }^{* *} p<.01$ (two-tailed); Standard errors are reported in parentheses. 
Table 6 Summary statistics and correlation matrix - Panel A: Summary statistics

\begin{tabular}{|c|c|c|c|c|}
\hline & Mean & Standard deviation & Min & $\operatorname{Max}$ \\
\hline ENV POS & $\begin{array}{l}0.04^{a} 0.07^{e} \\
0.04^{b} 0.06^{f} \\
0.01^{c} 0.02^{g} \\
0.01^{d} 0.04^{h}\end{array}$ & $\begin{array}{l}0.10^{a} 0.18^{e} \\
0.08^{b} 0.16^{f} \\
0.04^{c} 0.09 g \\
0.05^{d} 0.12^{h}\end{array}$ & $\begin{array}{l}0.00^{a} 0.00^{\mathrm{e}} \\
0.00^{b} 0.00^{f} \\
0.00^{\mathrm{c}} 0.00^{\mathrm{g}} \\
0.00^{d} 0.00^{h}\end{array}$ & $\begin{array}{l}0.80^{a} 1.00 \mathrm{e} \\
0.50^{b} 1.00^{f} \\
0.20^{\circ} 0.67 \mathrm{~g} \\
0.50^{d} 1.00^{h}\end{array}$ \\
\hline SOC POS & $\begin{array}{l}0.05^{a} 0.05^{e} \\
0.05^{b} 0.06^{f} \\
0.02^{c} 0.04^{g} \\
0.05^{d} 0.07^{h}\end{array}$ & $\begin{array}{l}0.07^{a} 0.12^{e} \\
0.07^{b} 0.13^{f} \\
0.03^{c} 0.10^{g} \\
0.07^{d} 0.13^{h}\end{array}$ & $\begin{array}{l}0.00^{a} 0.00^{e} \\
0.00^{b} 0.00^{f} \\
0.00^{c} 0.00 g \\
0.00^{d} 0.00^{h}\end{array}$ & $\begin{array}{l}0.54^{a} 1.00^{e} \\
0.45^{b} 0.91^{f} \\
0.19^{c} 0.58^{g} \\
0.42^{d} 0.75^{h}\end{array}$ \\
\hline ENV NEG & $\begin{array}{l}0.04^{a} 0.02^{e} \\
0.09^{b} 0.03^{f} \\
0.01^{c} 0.01^{g} \\
0.01^{d} 0.01^{h}\end{array}$ & $\begin{array}{l}0.11^{a} 0.07^{e} \\
0.14^{b} 0.10^{f} \\
0.05^{c} 0.03^{g} \\
0.04^{d} 0.05^{h}\end{array}$ & $\begin{array}{l}0.00^{a} 0.00^{e} \\
0.00^{b} 0.00^{f} \\
0.00^{c} 0.00^{g} \\
0.00^{d} 0.00^{h}\end{array}$ & $\begin{array}{l}0.71^{a} 0.83^{e} \\
0.71^{b} 1.00^{f} \\
0.29^{c} 0.20^{g} \\
0.29^{d} 0.60^{h}\end{array}$ \\
\hline SOC NEG & $\begin{array}{l}0.06^{a} 0.07^{e} \\
0.07^{b} 0.06^{f} \\
0.05^{c} 0.06^{g} \\
0.08^{d} 0.07^{h}\end{array}$ & $\begin{array}{l}0.06^{a} 0.10^{e} \\
0.07^{b} 0.09^{f} \\
0.05^{c} 0.09 g \\
0.08^{d} 0.10^{h}\end{array}$ & $\begin{array}{l}0.00^{a} 0.00^{e} \\
0.00^{b} 0.00 f \\
0.00^{c} 0.00^{g} \\
0.00^{d} 0.00^{h}\end{array}$ & $\begin{array}{l}0.50^{a} 0.64^{e} \\
0.38^{b} 0.63^{f} \\
0.19^{c} 0.33^{g} \\
0.50^{d} 0.64^{h}\end{array}$ \\
\hline ROA & $\begin{array}{l}0.34^{a} 0.28^{e} \\
0.19^{b} 0.19^{f} \\
0.43^{c} 0.36^{g} \\
0.61^{d} 0.57^{h}\end{array}$ & $\begin{array}{l}0.28^{a} 0.57^{e} \\
0.17^{b} 0.44^{f} \\
0.22^{c} 0.38^{g} \\
0.26^{d} 0.75^{h}\end{array}$ & $\begin{array}{l}-1.71^{a}-25.22^{e} \\
-0.31^{b}-6.00^{f} \\
-0.00^{c}-4.90^{g} \\
0.06^{d}-22.50^{h}\end{array}$ & $\begin{array}{l}3.39^{a} 11.01^{e} \\
1.91^{b} 12.53^{f} \\
1.13^{c} 2.72^{g} \\
2.19^{d} 4.30^{h}\end{array}$ \\
\hline Log EMP & $\begin{array}{l}1.05^{a} 0.32^{e} \\
1.40^{b} 1.03^{f} \\
1.44 c 0.87^{g} \\
2.83^{d} 2.53^{h}\end{array}$ & $\begin{array}{l}1.76^{a} 2.36^{e} \\
1.56^{b} 1.10^{f} \\
1.35^{c} 1.96 g \\
1.61^{d} 1.85^{h}\end{array}$ & $\begin{array}{l}-5.52^{a}-6.91^{e} \\
-6.21^{b}-6.91^{f} \\
-2.76^{c}-6.91 g \\
-4.42^{d}-6.91^{h}\end{array}$ & $\begin{array}{l}5.87^{a} 6.38^{e} \\
6.06^{b} 6.43^{f} \\
4.01^{c} 4.27 g \\
7.65^{d} 7.70^{h} \\
\end{array}$ \\
\hline Capital Intensity (Cl) & $\begin{array}{c}16.10^{\mathrm{a}} 22.76^{\mathrm{e}} \\
3.13^{b} 10.02^{f} \\
16.65^{c} 1.13^{g} \\
0.59^{d} 0.73^{h}\end{array}$ & $\begin{array}{c}710.59^{a} 479.76^{e} \\
15.99^{b} 212.81^{f} \\
231.97^{\circ} 3.61^{g} \\
0.57^{d} 1.20^{h}\end{array}$ & $\begin{array}{c}-6.88^{a} 0.01^{e} \\
0.09^{b} 0.04 f \\
0.08^{c} 0.00 \mathrm{~g} \\
0.16^{d} 0.12^{h}\end{array}$ & $\begin{array}{c}54344.30^{\mathrm{a} 2} 28809.22^{\mathrm{e}} \\
445.23^{\circ} 8684.45^{f} \\
4578.52^{\mathrm{c}} 46.92^{\mathrm{g}} \\
17.69^{d} 17.68^{\mathrm{h}}\end{array}$ \\
\hline
\end{tabular}

2000-2008 (Manufacturer (a); Transportation (b); Wholesaler (c); Retailer $\left({ }^{(d)}\right)$ ) 2009-2014 (Manufacturer (e); Transportation (f); Wholesaler ( $(9)$; Retailer $(h)$ ) 
Table 7 Summary statistics and correlation matrix - Panel B: Correlation matrix

\begin{tabular}{|c|c|c|c|c|c|c|c|}
\hline & $\begin{array}{l}\text { ENV } \\
\text { POS }\end{array}$ & $\begin{array}{l}\text { SOC } \\
\text { POS }\end{array}$ & $\begin{array}{l}\text { ENV } \\
\text { NEG }\end{array}$ & $\begin{array}{l}\text { SOC } \\
\text { NEG }\end{array}$ & ROA & $\begin{array}{l}\log \\
\text { EMP }\end{array}$ & $\mathrm{Cl}$ \\
\hline ENV POS & 1 & $\begin{array}{l}0.66^{e} \\
0.52^{f} \\
0.31^{g} \\
0.63^{h}\end{array}$ & $\begin{array}{l}0.34^{e} \\
0.48^{f} \\
0.03^{g} \\
0.29^{h}\end{array}$ & $\begin{array}{l}0.16^{e} \\
0.26^{f} \\
0.06^{g} \\
0.37^{h}\end{array}$ & $\begin{array}{c}0.03^{e} \\
-0.06^{f} \\
0.02^{g} \\
0.01^{h}\end{array}$ & $\begin{array}{l}0.40^{e} \\
0.32^{f} \\
0.22^{g} \\
0.36^{h}\end{array}$ & $\begin{array}{l}-0.02^{e} \\
-0.02^{f} \\
-0.04^{f} \\
-0.03^{h}\end{array}$ \\
\hline SOC POS & $\begin{array}{l}0.43^{a} \\
0.31^{b} \\
0.02^{c} \\
0.37^{d}\end{array}$ & 1 & $\begin{array}{l}0.26^{e} \\
0.30^{f} \\
0.05^{g} \\
0.21^{h}\end{array}$ & $\begin{array}{c}-0.09^{e} \\
0.15^{f} \\
-0.08^{g} \\
0.29^{h}\end{array}$ & $\begin{array}{c}0.03^{e} \\
-0.04^{f} \\
0.03^{g} \\
0.05^{h}\end{array}$ & $\begin{array}{l}0.38^{e} \\
0.35^{f} \\
0.33^{g} \\
0.43^{h}\end{array}$ & $\begin{array}{l}-0.01^{e} \\
-0.03^{f} \\
-0.05^{g} \\
-0.06^{h}\end{array}$ \\
\hline ENV NEG & $\begin{array}{l}0.34^{a} \\
0.34^{b} \\
0.27^{c} \\
0.03^{d}\end{array}$ & $\begin{array}{c}0.34^{a} \\
0.25^{b} \\
-0.04^{c} \\
0.01^{d}\end{array}$ & 1 & $\begin{array}{l}0.27^{e} \\
0.28^{f} \\
0.15^{g} \\
0.37^{h}\end{array}$ & $\begin{array}{l}-0.02^{e} \\
-0.07^{f} \\
-0.03^{g} \\
-0.05^{h}\end{array}$ & $\begin{array}{c}0.28^{e} \\
0.21^{f} \\
.01^{g} \\
0.18^{h}\end{array}$ & $\begin{array}{c}-0.01^{e} \\
-0.01^{f} \\
-0.03 g \\
0 . x X^{h}\end{array}$ \\
\hline SOC NEG & $\begin{array}{l}0.14^{a} \\
0.09^{b} \\
0.01^{c} \\
0.07^{d}\end{array}$ & $\begin{array}{c}0.13^{a} \\
0.27^{b} \\
-0.20^{c} \\
0.27^{d}\end{array}$ & $\begin{array}{l}0.36^{a} \\
0.22^{b} \\
0.06^{c} \\
0.22^{d}\end{array}$ & 1 & $\begin{array}{c}0.01^{e} \\
0.03^{f} \\
-0.03^{g} \\
-0.02^{h}\end{array}$ & $\begin{array}{l}0.11^{e} \\
0.16^{f} \\
0.04^{g} \\
0.21^{h}\end{array}$ & $\begin{array}{l}-0.02^{e} \\
-0.03^{f} \\
-0.05^{g} \\
-0.07^{h}\end{array}$ \\
\hline ROA & $\begin{array}{c}0.01^{a} \\
-0.21^{b} \\
0.03^{c} \\
0.01^{d}\end{array}$ & $\begin{array}{c}0.12^{a} \\
-0.13^{b} \\
-0.03^{c} \\
-0.03^{d}\end{array}$ & $\begin{array}{l}-0.09^{a} \\
-0.27^{b} \\
-0.13^{c} \\
-0.13^{d}\end{array}$ & $\begin{array}{c}-0.07^{a} \\
0.00^{b} \\
-0.05^{c} \\
-0.05^{d}\end{array}$ & 1 & $\begin{array}{c}0.15^{e} \\
-0.07^{f} \\
0.08^{g} \\
-0.07^{h}\end{array}$ & $\begin{array}{c}-0.05^{e} \\
-0.06^{f} \\
-0.17 g \\
0.30 h\end{array}$ \\
\hline Log EMP & $\begin{array}{c}0.37^{a} \\
0.16^{b} \\
-0.03^{c} \\
0.08^{d}\end{array}$ & $\begin{array}{c}0.46^{a} \\
0.46^{b} \\
-0.04^{c} \\
0.47^{d}\end{array}$ & $\begin{array}{c}0.43^{a} \\
0.29^{b} \\
-0.09^{c} \\
0.10^{d}\end{array}$ & $\begin{array}{c}0.19^{a} \\
0.35^{b} \\
-0.05^{c} \\
0.38^{d}\end{array}$ & $\begin{array}{c}0.17^{a} \\
-0.07^{b} \\
-0.12^{c} \\
-0.11^{d}\end{array}$ & 1 & $\begin{array}{l}-0.07 e \\
-0.17^{f} \\
-0.21 g \\
-0.15^{h}\end{array}$ \\
\hline $\mathrm{Cl}$ & $\begin{array}{c}-0.01^{a} \\
-0.02^{b} \\
-0.02^{c} \\
0.04^{d}\end{array}$ & $\begin{array}{c}0.01^{a} \\
-0.03^{b} \\
-0.04^{c} \\
0.00^{d}\end{array}$ & $\begin{array}{l}-0.01^{a} \\
-0.02^{b} \\
-0.02^{c} \\
-0.07^{d}\end{array}$ & $\begin{array}{c}-0.00^{a} \\
0.03^{b} \\
-0.06^{c} \\
0.03^{d}\end{array}$ & $\begin{array}{l}-0.07^{a} \\
-0.10^{b} \\
-0.14^{c} \\
-0.27^{d}\end{array}$ & $\begin{array}{l}-0.02^{a} \\
-0.15^{b} \\
-0.14^{c} \\
-0.14^{d}\end{array}$ & 1 \\
\hline
\end{tabular}

2000-2008 (Manufacturer (a); Transportation (b); Wholesaler (c); Retailer $\left({ }^{(d)}\right)$

2009-2014 (Manufacturer (e); Transportation (f); Wholesaler (g); Retailer (h))

Trisha Anderson, Ph.D., PMP, CSCP, is an Associate Professor at Texas Wesleyan University since 2009. She received her Ph.D. in Management Science from the University of Massachusetts, Amherst. Prior to teaching, she worked as an inventory manager and a marketing campaign project manager. She received the Engaging Educator Award, the Silver Star Award, the General Board of Higher Education and Ministry of the United Methodist Church Exemplary Teacher Award, and the John Maddux Jr. Faculty Award. She has published her research in journals such as the European Journal of Operation Operational Research, Omega, and the International Journal of Public Sector Management, among others.

Zugang Liu, Ph.D., is an Associate Professor of Business Administration at the Pennsylvania State University - Hazleton. He holds a B.S. in civil engineering from Tsinghua University in China and an M.S. in civil engineering from the University of Massachusetts, Amherst, where he also received his Ph.D. in management. His research into operations and supply chain management, management information systems, and investment has been published in various journals, including European Journal of Operational Research, International Journal of Production Economics, Decision Support Systems, Naval Research Logistics, Omega and the Journal of Banking and Finance, among others.

Jose Cruz, PhD, is an Associate Professor of Operations and Information Management and and the Associate Dean for Graduate Programs, School of Business, the University of Connecticut. Dr. Cruz has published his research in European Journal of Operational Research, Naval Research Logistics, Decision Support Systems, International Journal of Production Research, International Journal of Production Economics, Environment \& Planning B, Journal of Cleaner Production, Mathematical and Computer Modelling, Computational Management Science, and Quantitative Finance. He received the School of Business Ackerman Scholarship Award (two times), Outstanding Graduate Teaching Award, Outstanding Undergraduate Teaching Award, and the Distinguished Service Award. 
Jia Wang, Ph.D., is an Associate Professor of Finance at Rohrer College of Business, Rowan University. She holds a B.S. in Accounting from Tsinghua University, China, an M.S. in Statistics and a Ph.D. in Finance from the University of Massachusetts, Amherst. Her research interests focus on empirical asset pricing, integration of operations and finance and machine learning in finance. She has published in a number of journals including Journal of Banking and Finance, European Journal of Operational Research, International Journal of Production Economics, International Review of Financial Analysis, Journal of Investing, among others. 